\section{The prevention and treatment of cerebral ischemia}

William L. Lanier MD
$\mathrm{I}$ SCHEMIC brain insults, and injury resulting from those insults, are disturbingly common in hospitalized patients, including those undergoing surgery. The basis of this is as follows: In the general population, stroke is a common cause of morbidity and mortality in industrialized nations. For example, in the United States, stroke is the third leading cause of death (ranking only behind heart disease and cancer) and is the leading cause of major disability. ${ }^{1}$ Another cause of ischemic brain injury results from surgical interventions and anesthetic techniques. In this category, neurosurgical and cardiac surgical patients are at relatively high risk, although other patients may be at risk as well. It is reported that, in patients having carotid endarterectomy, approximately $23 \%$ will have electroencephalographic changes of ischemia at the time the carotid artery is cross-clamped to facilitate surgical repair. ${ }^{2}$ In this population, the risk of long-term neurologic deficits resulting from perioperative ischemia is approximately $3-4 \%{ }^{2,3}$ In cardiac surgery patients, approximately $16-80 \%$ of patients will have short-term neurological or psychiatric deficits and, of these, half will experience sustained deficits. ${ }^{4,5}$ These deficits in cardiac surgery patients are believed to result from showers of air and particulate debris flushed into the cerebral circulation during cardiopulmonary bypass, and the ischemia is exacerbated by periods of systemic hypotension or shock.

Based on these data, it is likely that the clinician caring for adults will encounter patients who are at high-risk for ischemic brain injury or are having stroke-in-evolution. Thus, it is important to understand the basic principles for treating cerebral ischemia and, if possible, develop techniques to prevent newonset or repeat episodes of ischemia.

Types of ischemic insults and expectations for recovery Cerebral ischemic insults are divided into those that are complete or incomplete. With complete cerebral ischemia, there is no blood flow to the brain whatsoever. This is the type of ischemia encountered during cardiac arrest, before resuscitative measures are initiat- ed. Incomplete cerebral ischemia occurs in two forms. In the first, incomplete global ischemia, there is hypoperfusion of the entire brain. This is most commonly encountered with profound systemic shock. In the second form, focal ischemia, portions of the brain may experience severe ischemia, while other portions of the brain are normal. Classic embolic or thrombotic stroke is the most common form of focal ischemia.

Expectations for recovery will depend on the type of ischemia. For example, in humans experiencing cardiac arrest, it is generally assumed that irreversible brain injury will occur with arrest durations in excess of five to eight minutes. ${ }^{6,7}$ In contrast, with focal cerebral ischemia, much longer durations of ischemia can be tolerated. ${ }^{8}$

Repetitive cerebral ischemic insults may have additive or supraadditive effects on brain injury. ${ }^{9}$ Such a phenomenon may explain why humans experiencing cardiac arrest tolerate much less ischemia than laboratory animals exposed to complete ischemia. ${ }^{7}$ In contrast to the square wave of ischemia induced in laboratory animals, humans often precede and follow a period of cardiac arrest with periods of hypoperfusion, hypoxemia, acidosis, and other aberrations of physiology. Of patients hospitalized after resuscitation from out-ofhospital cardiac arrest, $57 \%$ will experience recurrent ventricular fibrillation or ventricular tachycardia, and $25 \%$ will experience cardiogenic shock. ${ }^{10}$ Similar problems, resulting from abberations of cardiopulmonary function and vasospasm, may accompany patients having focal cerebral ischemia. ${ }^{11-13}$ Based on these factors, the clinician should be attentive to treating not only the sentinel ischemic event (e.g., cardiac arrest, stroke), but also systemic physiology surrounding those events, if optimal neurologic recovery is to be achieved.

Lessening the duration and intensity of the ischemic insult

Rapid-response treatment

Because outcome following cerebral ischemia is so 
closely coupled to the duration of the ischemic insult, modern therapy has focused on rapid treatment of brain ischemia. With cardiac arrest, this has resulted in efforts to rapidly defibrillate the heart, as opposed to persisting with chest compression-facilitated support of circulation. ${ }^{14,15}$ Recent efforts to optimize response times outside the hospital have included the placement of lightweight, portable defibrillators in roving police cars within the community. ${ }^{15}$ Regardless of the clinical setting, rapid response and restoration of endogenous circulation correlates with improved neurologic outcome. . $^{75}$

Rapid response is also critical in the treatment of focal cerebral ischemia. ${ }^{14}$ When initiated shortly after the onset of ischemia, restoration of cerebral circulation using thrombolytic therapies may result in improved patient outcomes. ${ }^{14,16}$

\section{Optimizing cerebral perfusion pressure and blood oxy- gen content}

The initial approach to the patient having an ischemic brain insult should focus on improving the delivery of oxygen-rich blood to the brain. This approach has two components: improving cerebral perfusion pressure and improving blood oxygen content.

\section{OPTIMIZING CEREBRAL PERFUSION.}

In order to have adequate cerebral perfusion, it is necessary to supply an adequate cerebral perfusion pressure (CPP). This pressure is defined as follows:

$$
\mathrm{CPP}=\mathrm{MAP} \text { - ICP }
$$

where MAP is mean arterial blood pressure and ICP is intracranial pressure.

In normal subjects, cerebral blood flow (CBF) will remain relatively constant over a wide variety of cerebral perfusion pressures due to the influence of autoregulation. In general, it is assumed that autoregulation occurs in normal brain over the CPP range of 50-150 $\mathrm{mm} \mathrm{Hg} .{ }^{17}$ However, Drummond recently reviewed the literature and determined that the lower pressure limit for autoregulation is far from clear, and may be meaningfully greater than $50 \mathrm{~mm} \mathrm{Hg}$, even in normal patients. ${ }^{18}$ The lower limit of autoregulation also is increased in previously hypertensive patients, because the autoregulation curve is shifted to the right (i.e., higher pressures will be required to maintain $\mathrm{CBF}$ ). ${ }^{17}$

In subjects having brain ischemia, autoregulation may be impaired or absent, thus, $\mathrm{CBF}$ will be more linearly correlated with CPP.

In choosing the ideal CPP for the patient having cerebral ischemia, it is perhaps best to maintain the patient at his historical baseline blood pressure or slightly above. If blood pressure is intentionally elevated above historical controls, attention should be given to monitoring for myocardial ischemia, since many patients at risk for cerebral ischemia will also be at risk for myocardial ischemia.

Because CPP is dependent on ICP, cerebral perfusion management should include measures to prevent or treat excessive increases in ICP. In the past, $\mathrm{PaCO}_{2}$ manipulation has been used as one of many methods to treat ICP in patients having cerebral ischemia, based on the assumption that the hypocapnia might also benefit regional $\mathrm{CBF}$ via a reverse cerebral steal (or "Robin Hood") effect. ${ }^{19,20}$ However, recent research suggests that hypocapnia will not beneficially affect CBF distribution in the ischemic brain, ${ }^{19,20}$ but, instead, may adversely influence blood flow distribution. ${ }^{20}$ Thus, in the setting of cerebral ischemia, $\mathrm{PaCO}_{2}$ maintenance at or near normocapnic values is recommended.

\section{OPTIMIZING BLOOD OXYGEN CONTENT.}

Attention also should be paid to optimizing blood oxygen content. This will involve the treatment of anemia and the use of supplemental oxygen. In the patient with persistent hypoxia, invasive monitoring should be considered to guide physiologic manipulation.

\section{CLINICAL EXPERIENCE WITH BLOOD PRESSURE AND HEMATOCRIT ALTERATIONS.}

There is a large amount of literature on the use of hypertensive, hypervolemic, hemodilution $(\mathrm{HHH})$ therapy for the treatment of cerebral ischemia. ${ }^{13}$ In theory, such treatment will improve blood rheology and improve oxygen delivery to the brain. However, enthusiasm for the aggressive use of this technique has been tempered by concern for cerebral and systemic side effects (e.g., cerebral edema, cardiac arrhythmias, pulmonary edema). ${ }^{11,13}$

At the other extreme, hemodilution and induced hypotension are sometimes used in patients without baseline cerebral ischemia, in an attempt to lessen blood loss during surgery (e.g., spine surgery). The value of this technique in reducing blood loss is debatable. It should be noted, however, that in these patient populations, the combination of hypotension and anemia, whether intentional or not, should increase the likelihood of ischemic injury to the central nervous system. The growing number of reports of vision loss associated with hypotension and anemia is but one manifestation of this problem. ${ }^{21}$

\section{Blood glucose control}

Increases in blood glucose and brain glucose concen- 
tration at the time of a cerebral ischemic event will worsen post-ischemic neurologic outcome. ${ }^{22,23}$ The basis of this phenomenon is that, during periods of cellular hypoxia or anoxia, the anaerobic metabolism of glucose will result in intracellular lactic acidosis. ${ }^{23}$ Hydrogen ions emanating from this metabolism are directly toxic to neurons and glia; however, the lactate does not appear to be toxic. This relationship between hyperglycemia and worsened outcome is observed in juvenile and adult subjects. In contrast, neonates do not appear to be adversely affected by mild hyperglycemia. ${ }^{23}$

Glucose exacerbation of ischemic neurologic injury occurs in the setting of both complete ischemia and incomplete ischemia. ${ }^{23}$ Further, it does not appear to matter how the hyperglycemia originates. Specifically, glucose enhancement of ischemic neurologic injury has been reported with recent food ingestion, physiologic stress, glucose infusion, diabetes mellitus, and corticosteroid use. .2-24 $^{24}$

In the patient at risk for ischemic neurologic injury, treatment will include management of physiologic stress, avoidance or judicious use of glucose containing fluids, and treatment of hyperglycemia with volume expansion and insulin. Insulin will benefit the brain by both reducing brain glucose concentration and also by a direct, cerebroprotective effect that is glucose independent. ${ }^{23}$

Blood glucose concentrations should be maintained in the normoglycemic range as long as the patient is at risk for cerebral ischemia. If an ischemic event should occur, blood glucose increases of as little as $40 \mathrm{mg} \cdot \mathrm{dl}^{-1}$ may result in worsened outcome. ${ }^{22}$ Thus, no patient at risk for ischemia should have persistent blood glucose concentrations in excess of $\mathbf{2 5 0}$ $\mathrm{mg} \cdot \mathrm{dl}^{-1}{ }^{23}$ Efforts also should be made to avoid excessively aggressive treatment resulting in bypoglycemia, because this can result in irreversible brain injury, regardless of whether there is a cerebral ischemic insult or not. ${ }^{23}$

For further recommendations on blood glucose management, the clinician may wish to consult the recent review of Wass and Lanier. ${ }^{23}$

\section{Steroids}

Steroidal compounds have commonly been used in neurologically impaired patients, including those having ischemic brain injury, under the assumption that "the drugs may not do any good, but they certainly will do no harm." We now know that this assumption is incorrect. In contrast to limited evidence of protection in acute spinal cord injury in humans, ${ }^{25}$ traditional corticosteroid drugs may exacerbate ischemic brain injury. The latter effect is largely related to corticosteroid- induced increases in blood and brain glucose. Hyperglycemia alone can account for the detrimental effects of corticosteroid drugs in animal models and human trials of ischemia, and a human trial of closed head injury (see Wass and Lanier ${ }^{23}$ and Wass et al..$^{24}$ for review). Thus, traditional corticosteroids are not recommended in the treatment of ischemic brain injury.

Recent research has attempted to separate the detrimental hyperglycemia-inducing effects of the corticosteroids from their potentially beneficial antioxidant effects. One result of this research is the introduction of the 21-aminosteroid compounds, or lazaroids, of which tirilazad is the prototype. This drug has demonstrated some promise in the treatment of cerebral ischemia in animal models, and preliminary results in humans having aneurysmal subarachnoid hemorrhage were promising. ${ }^{26}$ However, disappointing results in subsequent trials have currently hindered the introduction of this drug for routine clinical use.

\section{Temperature management}

It has long been appreciated that profound reductions in temperature (e.g. to $17^{\circ} \mathrm{C}$ ) are protective for the human brain. Under such conditions, humans placed on cardiopulmonary bypass-support of circulation can be exposed to periods of circulatory arrest of one hour without experiencing irreversible brain injury ${ }^{6,27}$ This technique is sometimes used to facilitate surgical repair of complex cardiac or cerebrovascular anomalies. ${ }^{27}$

Efforts to reduce temperature therapeutically to $<30^{\circ} \mathrm{C}$ outside the setting of cardiopulmonary bypass-assisted circulation have met with dismal results. This is because the temperature reductions produce aberrations of systemic physiology that are detrimental to the patient, regardless of whether there is a cerebral ischemic insult or not. ${ }^{6,27}$

It has long been assumed that any temperature-mediated cerebral protection is the result of a reduction in cerebral metabolic rate. ${ }^{17}$ Perhaps allegiance to this assumption, combined with the above-mentioned experience with hypothermia outside cardiopulmonary bypass, delayed investigation into the effect of mild reductions in temperature (i.e., temperature reductions above $30^{\circ} \mathrm{C}$ ) on post-ischemic outcome. We now know, however, that such small reductions in temperature can be profoundly protective in animal models. ${ }^{6,27}$ Further, mild hypothermia will improve outcome when initiated either before or shortly after the ischemic insult. ${ }^{27}$

Since 1987, numerous studies in animal models have consistently demonstrated that temperature reductions of $<6^{\circ} \mathrm{C}$ protected the brain from ischemic injury. ${ }^{6,27}$ In contrast, temperature increases worsened outcome. $^{28,29}$ These alterations in outcome did not 
result from changes in metabolic rate, as determined by studies of high-energy phosphate metabolism and lactate accumulation. ${ }^{6,27}$ Instead, the basis of altered outcome is believed to result from a variety of factors, including a) alterations in ion homeostasis (including calcium and potassium fluxes), b) increased membrane stability (including the blood-brain barrier), c) altered enzyme function, d) alterations in neurotransmitter release or uptake, and e) changes in free radical production or scavenging. ${ }^{6,27}$

The minimal temperature change required to alter outcome was characterized in the studies of Warner $e t$ $a l^{30}$ and Wass et $a l^{28}$ In the former, temperature alterations of $1.2^{\circ} \mathrm{C}$ correlated with a three-fold change in infarct volume in a rat model of focal ischemia. In the latter, temperature changes of only $1^{\circ} \mathrm{C}$ were sufficient to alter outcome in a canine model of complete ischemia.

Unfortunately, currently there are no studies that validate that induced hypothermia will protect the human brain from ischemic injury (though there is evidence for a tendency toward protection in humans suffering from closed head injury). ${ }^{27,31}$ Until such research is available, there is some concern that temperature reduction in humans should be used with caution, because excessive temperature reduction (i.e., to $<35^{\circ} \mathrm{C}$ ) will increase the likelihood of systemic side effects. ${ }^{6,27,32}$

As recently reviewed, ${ }^{29}$ fever should adversely affect outcome following cerebral ischemia. Of concern, Albrecht $e t a l$. reported that hospitalized patients at risk for cerebral ischemic injury have a high incidence of fever (i.e., $70 \%$ after subarachnoid hemorrhage and $83 \%$ following resuscitation from cardiac arrest) and, in these patients, febrile episodes largely go untreated. ${ }^{29}$ Based on the data from laboratory studies, one would anticipate that more proactive treatment of fever should help improve postischemic neurologic recovery.

\section{Use of anesthetics}

Anesthetic drugs can benefit the patient with acute brain injury by a variety of mechanisms, including control of seizures and ICP. Much attention has also been paid to using anesthetics as direct cerebral protectants. This topic has been reviewed recently by Polis and Lanier. ${ }^{33}$

\section{Barbiturates}

The greatest evidence for cerebral protection is demonstrated with the barbiturates. ${ }^{33}$ These drugs are not effective in the treatment of cerebral ischemia associated with cardiac arrest, ${ }^{34}$ but they are useful in the treatment of focal cerebral ischemia. ${ }^{33}$
In animal models of focal cerebral ischemia, the barbiturates typically reduce infarct size. $^{33}$ Further, Neussmeir et al. reported that thiopental administration reduced the incidence of postoperative neurological and psychiatric complications in cardiac surgery patients. ${ }^{35}$ This is the only report in humans of anesthetic-related cerebral protection, as identified using a prospective randomized study design. ${ }^{33,35}$

Cerebral protection by the barbiturates has long been attributed to their ability to reduce cerebral metabolic rate and redistribute $\mathrm{CBF}^{33}$ Such theory dictates the use of large barbiturate doses to obtain maximal cerebral protection. However, this practice, as well as the theory for protection, were recently questioned by Warner $e t$ al. ${ }^{36}$ This study demonstrated that cerebral protection by pentobarbital did not correlate with drug dose or the extent of metabolic depression in a rat model of focal cerebral ischemia.

\section{Other metabolic depressant anesthetics}

Although a variety of metabolic depressant anesthetics have been evaluated for cerebroprotective properties in animal models, none compares to the cerebral protection observed with the barbiturates. As reviewed by Polis and Lanier ${ }^{33}$, of the available reports, the fraction of studies demonstrating cerebral protection was as follows: barbiturates, 17 of 19 studies; isoflurane, 4 of 8; etomidate, 0 of 2 ; and propofol, 1 of 3 . Of note, etomidate actually worsened outcome in the two cited studies. In these collective studies, all positive examples of cerebral protection by non-barbiturates occurred in the same model (i.e., unilateral carotid artery occlusion plus induced hypotension). ${ }^{33}$ However, in this model, cerebral protection did not correlate with alterations in metabolic rate, but instead correlated with alterations in catecholamine metabolism.

There is no evidence for cerebral protection by nonbarbiturates in humans. ${ }^{33}$ Although isoflurane has been reported by Michenfelder $e t$ al. to lessen "critical CBF" and the incidence of cerebral ischemia during carotid endarterectomy surgery, there was no effect on longterm outcome. ${ }^{2}$ The reason for this was, perhaps, best identified by Lozada $e t$ al. ${ }^{37}$ Retrospectively reviewing the same patient population as Michenfelder $e t a l .^{2}$, they determined that $79 \%$ of the neurological deficits resulted from postoperative ischemic insults, and thus should not have been influenced by intraoperative choice of anesthetics.

\section{Use of receptor-specific cerebroprotective drugs Calcium entry blockers}

Although a variety of calcium entry blocking drugs is approved for human use, evidence for cerebral protec- 
tion in humans is almost exclusively related to the use of nimodipine for the treatment of cerebral vasospasm. ${ }^{38}$ In patients having vasospasm after subarachnoid hemorrhage, nimodipine will improve outcome in humans; however, the improvement may be related to factors other than alterations in CBF. Specifically, nimodipine may be directly cerebroprotective. ${ }^{38}$

Because of this favourable experience, nimodipine is routinely used for the prophylaxis and treatment of vasospasm in patients having rupture of a cerebral aneurysm. ${ }^{26,38}$

\section{Excitatory amino acid antagonists}

There is a large amount of experimental evidence in animal models that the release of excitatory amino acids (e.g., glutamate and aspartate) during ischemia will modulate post-ischemic outcome. ${ }^{7,33}$ Further, EAAblocking drugs may improve outcome in these models.

Unfortunately, EAA-blocking drugs have not gained acceptance for the treatment of cerebral ischemia in humans, in large measure because of their side effects. This family of drugs, which includes phencyclidine ("angel dust") and ketamine, tends to cause psychologic problems, including hallucinations, and may lower seizure threshold. ${ }^{33}$

\section{Summary}

Although the major focus of recent cerebral protection research has been aimed at developing receptorspecific drugs, this effort has currently resulted in few improvements in patient outcome. Until advances in pharmacology translate to improvements in humans, the clinician and his patients will be well served by using more traditional techniques to prevent and treat cerebral ischemic events. This approach will involve interventions to a) identify patients who are experiencing or are at risk for developing cerebral ischemia, and b) alter systemic physiology in an attempt to lessen the duration and severity of any ischemic insults. Initial therapy should include interventions to improve cerebral perfusion and the oxygen carrying capacity of the blood. Once this is accomplished, measures should be taken to control blood glucose concentrations and treat fever. In otherwise stable surgical patients, mild reductions in patient temperature also may be of benefit, provided the temperature reductions do not introduce problems in systemic physiology and the patient is rewarmed prior to awakening from general anesthesia. General anesthetic choice may be of importance in controlling intracranial pressure and seizure activity; however, if direct cerebral protection is desired, the anesthetic of choice should be a barbiturate. Finally, in the patient at risk for cere- bral vasospasm, nimodipine treatment should be considered. Collectively, these interventions should increase the patient's chance for optimal neurologic recovery following ischemia.

\section{References}

1 American Heart Association. 1998 Heart and Stroke Statistical Update. Dallas: American Heart Association, 1997: 13.

2 Michenfelder JD, Sundt TM Jr, Fode N, Sharbrough $F W$. Isoflurane when compared to enflurane and halothane decreases the frequency of cerebral ischemia during carotid endarterectomy. Anesthesiology 1987; 67: 336-40.

3 Fode NC, Sundt TM Jr, Robertson JT, Peerless SJ, Shields $C B$. Multicenter retrospective review of results and complications of carotid endarterectomy in 1981. Stroke 1986; 17: 370-6.

4 Slogoff S, Girgis KZ, Keats AS. Etiologic factors in neurophsychiatric complications associated with cardiopulmonary bypass. Anesth Analg 1982; 61: 903-11.

5 Mills $S A$. Cerebral injury and cardiac operations. Ann Thorac Surg 1993; 56: S86-S91.

6 Lanier WL. Cerebral metabolic rate and hypothermia: their relationship with ischemic neurologic injury. J Neurosurg Anesth 1995; 7: 216-21.

7 Wass CT, Lanier WL. Improving neurologic outcome following cardiac arrest. In: Rothenberg DM (Ed.). Anesthesiology Clinics of North America: Current Concepts in Cardiac Resuscitation, Philadelphia: W.B. Saunders Company, 1995: 869-903.

8 Zampella E, Morawetz RB, McDowell HA, et al. The importance of cerebral ischemia during carotid endarterectomy. Neurosurgery 1991; 29: 727-30.

9 Tomida S, Nowak TS Jr, Vass K, Lohr JM, Klatzo I. Experimental model for reperitive ischemic attacks in the gerbil: the cumulative effect of repeated ischemic insults. J Cereb Blood Flow Metab 1987; 7: 773-82.

10 Liberthson RR, Nagel EL, Hirschman JC, Nussenfeld $S R$. Prehospital ventricular defibrillation: prognosis and follow-up course. N Engl J Med 1974; 291: 317-21.

11 Solenski NJ, Haley EC, Kassell NF, et al. Medical complications of aneurysmal subarachnoid hemorrhage: a report of the multicenter, cooperative aneurysm study. Crit Care Med 1995; 23: 1007-17.

12 Kassell NF, Torner JC, Haley EC Jr, Jane JA, Adams HP, Kongable GL. The International Cooperative Study on the Timing of Aneurysm Surgery. Part I: Overall management results. J Neurosurg 1990; 73: 18-36.

13 Ullman JS, Bederson JB. Hypertensive, hypervolemic, hemodilutional therapy for aneurysmal subarachnoid hemorrhage. Is it efficacious? Yes. Crit Care Clin 1996; 12: 697-707. 
14 American Heart Association. Advanced Cardiac Life Support. Dallas, American Heart Association, 1997.

15 White RD, Asplin BR, Bugliosi TF, Hankins DG. High discharge survival rate after out-of-hospital ventricular fibrillation with rapid defibrillation by police and paramedics. Ann Emerg Med 1996; 28: 480-5.

16 Wardlaw JM, Warlow CP, Counsell C. Systematic review of evidence on thrombolytic therapy for acute ischaemic stroke. Lancet 1997; 350: 607-14.

17 Michenfelder JD. Anesthesia and the Brain: Clinical, Functional, Metabolic, and Vascular Correlates. New York: Churchill Livingstone, 1988: 3-34.

18 Drummond JC. The lower limit of autoregulation: Time to revise our thinking? Anesthesiology 1997; 86: 1431-3.

19 Gelb $A W$, Wong TG. Hypocapnia and hypotension-Do they still have a place in neuroanesthesia? In: Johnson JO, Sperry RJ, Stanley TH (Eds.). Neuroanesthesia. Dordrecht, The Netherlands: Kluwer Academic Publishers, 1997: 39-49.

20 Ruta TS, Drummond JC, Cole DJ. The effect of acute hypocapnia on local cerebral blood flow during middle cerebral artery occlusion in isoflurane anesthetized rats. Anesthesiology 1993; 78: 134-40.

21 Brown RH, Schauble JF, Miller NR. Anemia and hypotension as contributors to perioperative loss of vision. Anesthesiology 1994; 80: 222-6.

22 Lanier WL, Stangland KJ, Scheithauer BW, Milde JH, Michenfelder $J D$. The effects of dextrose infusion and head position on neurologic outcome after complete cerebral ischemia in primates: examination of a model. Anesthesiology 1987; 66: 39-48.

23 Wass CT, Lanier WL. Glucose modulation of ischemic brain injury: review and clinical recommendations. Mayo Clin Proc 1996; 71: 801-12.

24 Wass CT, Scheithauer BW, Bronk JT, Wilson RM, Lanier $W L$. Insulin treatment of corticosteroid- associated hyperglycemia and its effect on outcome after forebrain ischemia in rats. Anesthesiology 1996; 84: 644-51.

25 Bracken MB, Shepard MJ, Collins WF, et al. A randomized, controlled trial of methylprednisolone or naloxone in the treatment of acute spinal-cord injury. Results of the Second National Acute Spinal Cord Injury Study. New Engl J Med 1990; 322: 1405-11.

26 Kassell NF, Haley EC Jr, Apperson-Hansen C, Alves $W M$. Randomized, double-blind, vehicle-controlled trial of tirilazad mesylate in patients with aneurysmal subarachnoid hemorrhage: a cooperative study in Europe, Australia, and New Zealand. J Neurosurg 1996; 84: 221-8.

27 Wass CT, Lanier WL. Hypothermia-associated protection from ischemic brain injury: implications for patient management. Int Anesthesiol Clin 1996; 34: 95-111.
28 Wass CT, Lanier WL, Hofer RE, Scheithauer BW, Andrews $A G$. Temperature changes of $\leq 1^{\circ} \mathrm{C}$ alter functional neurologic outcome and histopathology in a canine model of complete cerebral ischemia.

Anesthesiology 1995; 83: 325-35.

29 Albrecht RF II, Wass CT, Lanier WL. Occurrence of potentially detrimental temperature alterations in hospitalized patients at risk for brain injury. Mayo Clin Proc 1998; 73: 629-35.

30 Warner DS, McFarlane C, Todd MM, Ludwig $P$, McAllister AM. Sevoflurane and halothane reduce focal ischemic brain damage in the rat. Possible influence on thermoregulation. Anesthesiology 1993; 79: 985-92.

31 Marion DW, Penrod LE, Kelsey SF, et al. Treatment of traumatic brain injury with moderate hypothermia. $\mathrm{N}$ Engl J Med 1997; 336: 540-6.

32 Sessler DI. Mild perioperative hypothermia. N Engl J Med 1997; 336: 1730-7.

33 Polis TZ, Lanier WL. An cvaluation of cerebral protection by anesthetics, with special reference to metabolic depression. In: Heyer EJ, Young WL (Eds.). Anesthesiology Clinics of North America: Anesthesia for the Patient with Neurologic Disease, Philadelphia: W.B. Saunders Company, 1997: 691-717.

34 Brain Resuscitation Clinical Trial I Study Group. Randomized clinical study of thiopental loading in comatose survivors of cardiac arrest. N Engl J Med 1986; 314: 397-403.

35 Nussmeier NA, Arlund C, Slogoff S. Neuropsychiatric complications after cardiopulmonary bypass: cerebral protection by a barbiturate. Anesthesiology 1986; 64: 165-70.

36 Warner DS, Takaoka S, Wu B, et al. Electroencephalographic burst suppression is not required to elicit maximal neuroprotection from pentobarbital in a rat model of focal cerebral ischemia. Anesthesiology 1996; 84: 1475-84.

37 Lozada LJ, Fode N, Piepgras D, Perkins WJ. Volatile anesthetic choice does not influence timing of perioperative stroke in patients undergoing carotid endarterectomy. Anesthesiology 1998; 89: A368.

38 Meyer FB. Calcium antagonists and vasospasm. Neurosurg Clin NA. 1990; 1: 367-76. 


\section{La prévention et le traitement de l'ischémie cérébrale}

I L est troublant de constater combien les accidents ischémiques cérébraux, et les lésions qui en résultent, sont fréquents chez les patients hospitalisés, y compris ceux qui doivent subir une intervention chirurgicale. En effet, dans la population générale, l'accident cérébral est une cause fréquente de morbidité et de mortalité dans les pays industrialisés. Par exemple, aux États-Unis, l'accident cérébral occupe le troisième rang des causes importantes de décès (juste après les maladies cardiaques et le cancer) et représente la principale cause d'invalidité majeure. ${ }^{1}$ Les autres causes de lésion cérébrale ischémique sont les conséquences des interventions chirurgicales et des techniques anesthésiques. Les patients de neurochirurgie et de chirurgie cardiaque sont relativement à haut risque, quoique d'autres patients peuvent être sujets aussi à ce genre d'accident. Par exemple, chez les patients qui subissent une endartériectomie carotidienne, $23 \%$ environ vont présenter des changements électroencéphalographiques ischémiques au moment du clampage total de l'artère carotide, réalisée pour faciliter la réparation chirurgicale. ${ }^{2}$ Dans cette population, le risque de déficits neurologiques à long terme est approximativement de $3-4 \%{ }^{2,3}$ Chez les patients de chirurgie cardiaque, de 16 à $80 \%$ environ vont souffrir de troubles neurologiques ou psychiatriques à court terme et, de ces patients, la moitié subira des déficits prolongés. ${ }^{4,5}$ On croit que ces déficits sont le résultat de jet d'air et de l'écoulement de débris particulaires dans la circulation cérébrale pendant la circulation extracorporelle et que l'ischémie est aggravée par des périodes d'hypotension ou de chỏc.

Ce disant, il est probable que le médecin traitant des adultes rencontrera des patients à haut risque de lésion cérébrale ischémique ou présentant un accident cérébral en évolution. Alors, il est important de comprendre les principes de base du traitement de l'ischémie cérébrale et, si possible, de mettre au point des techniques de prévention d'une nouvelle manifestation ou d'épisodes d'ischémie répétés.

\section{Types d'accidents ischémiques et pronostics de récupération}

Les accidents ischémiques cérébraux sont complets ou incomplets. Dans l'ischémie cérébrale complète, il n'y a aucun débit sanguin au cerveau. C'est le type d'ischémie qu'on retrouve pendant l'arrêt cardiaque, avant que les mesures de réanimation ne soient amorcées. L'ischémie cérébrale incomplète survient sous deux formes. Dans la première, l'ischémie globale incomplète, il y a une hypoperfusion du cerveau en entier. On l'observe généralement lors d'un choc systémique important. Dans la seconde forme, l'ischémie focale, certaines portions du cerveau peuvent subir des lésions ischémiques sévères, tandis que d'autres portions sont normales. Les accidents emboliques classiques ou thrombotiques sont la forme la plus courante de l'ischémie focale.

Le pronostic de la récupération dépend du type d'ischémie. Par exemple, chez les humains qui subissent un arrêt cardiaque, on suppose en général qu'une lésion cérébrale irréversible se produira lors d'un arrêt qui dure plus de cinq-huit minutes. ${ }^{6,7}$ Par ailleurs, dans l'ischémie cérébrale focale, de plus longues périodes d'ischémie sont tolérées. ${ }^{8}$

Des accidents ischémiques cérébraux répétitifs peuvent avoir des effets addditifs ou supra-additifs sur les lésions cérébrales. ${ }^{9}$ Un tel phénomène peut expliquer pourquoi les humains qui subissent un arrêt cardiaque supportent beaucoup moins l'ischémie que les animaux de laboratoire exposés à l'ischémie complète? Contrairement aux ondes carrées ischémiques provoquées chez les animaux en laboratoire, les humains présentent un arrêt cardiaque précédé ou suivi d'une période d'hypoperfusion, d'hypoxémie, d'acidose et d'autres troubles physiologiques. Parmi les patients hospitalisés après la réanimation pour arrêt cardiaque s'étant produit à l'extérieur de l'hôpital, 57 \% vont subir une fibrillation ventriculaire récurrente ou une tachycardie ventriculaire et $25 \%$, un choc cardiogénique. ${ }^{10}$ Des problèmes semblables résultant de désordres cardiopulmonaires fonctionnels et de vasospasme peuvent survenir chez des patients qui ont une ischémie cérébrale focale. ${ }^{11-13}$ En se basant sur ces facteurs, le clinicien doit être vigilant et traiter non seulement l'ischémie, comme une ischémie sentinelle (par ex. : l'arrêt cardiaque, l'accident vasculaire cérébral), mais aussi les perturbations physiologiques généralisées entourant ces événements, si la récupération neurologique optimale est envisagée. 
La réduction de la durée et de l'intensité de l'accident ischemique

\section{Traitement par intervention rapide}

Parce que l'évolution de l'ischémie cérébrale est très étroitement liée à la durée de l'accident ischémique, la thérapie moderne insiste sur la rapidité de son traitement. Dans le cas de l'arrêt cardiaque, cela s'est traduit en efforts pour assurer une rapide défibrillation cardiaque, à l'opposé du massage obstiné pour maintenir la circulation. ${ }^{14,15}$ Récemment, afin d'optimaliser le temps de réaction à l'extérieur de l'hôpital, on a introduit des défibrillateurs portables et légers dans les automobiles de la police qui parcourt les rues de la communauté. ${ }^{15}$ Quel que soit le cadre clinique, une réaction rapide et une restauration de la circulation endogène sont liées à l'évolution neurologique améliorée. 7,15

Une intervention rapide est aussi décisive dans le cas de l'ischémie cérébrale focale. ${ }^{14} \mathrm{La}$ restauration de la circulation cérébrale, amorcée tôt après le début de l'ischémie à l'aide de thérapies thrombolytiques, peut améliorer l'évolution du patient. ${ }^{14,16}$

\section{Optimaliser la pression de perfusion cérébrale et le con-} tenu du sang en oxygène

Lors d'un accident ischémique cérébral, il faut d'abord viser à améliorer la livraison de sang riche en oxygène au cerveau. Cette démarche présente deux composantes : améliorer la pression de perfusion cérébrale et améliorer le contenu du sang en oxygène.

\section{Optimaliser la perfusion cérébrale}

Si on veut obtenir une perfusion cérébrale suffisante, il faut fournir une pression de perfusion cérébrale adéquate (PPC). Cette pression se définit comme suit :

$$
\mathrm{PPC}=\mathrm{TAM}-\mathrm{PIC}
$$

où TAM est la tension artérielle moyenne et PIC est la pression intracrânienne.

Chez les sujets normaux, le débit sanguin cérébral (DSC) demeure relativement constant pour des pressions de perfusion cérébrale très différentes grâce à l'influence de l'autorégulation. En général, on estime que l'autorégulation se manifeste dans le cerveau normal pour des PPC allant de 50 à $150 \mathrm{mmHg} .{ }^{17}$ Cependant, à la suite d'une revue de la littérature, Drummond a récemment a conclu que la limite de pression inférieure de l'autorégulation est loin d'être claire et peut être plus élevée que $50 \mathrm{mmHg}$, ce qui est significatif, même chez les patients normaux. ${ }^{18} \mathrm{La}$ limite inférieure de l'autorégulation est aussi augmentée chez les patients déjà hypertendus parce que la courbe de l'autorégulation est déplacée vers la droite (c.-à-d., des pressions plus élevées sont nécessaires au maintien du DSC). ${ }^{17}$

Chez les sujets souffrant d'ischémie cérébrale, l'autorégulation peut être altérée ou absente, d'où le DSC sera davantage en corrélation linéaire avec la PPC.

En choisissant la PPC idéale pour le patient atteint d'ischémie cérébrale, il peut être préférable de maintenir la tension artérielle de base, habituelle, ou légèrement au-dessus. Si la tension artérielle est intentionnellement élevée au-dessus des niveaux de base, on doit surveiller la présence d'ischémie myocardique, car de nombreux patients à risque d'ischémie cérébrale le sont aussi de développer de l'ischémie myocardique.

La PPC étant dépendante de la PIC, la prise en charge de la perfusion cérébrale doit inclure des mesures de prévention, ou de traitement, d'augmentations excessives de la PIC. Dans le passé, la manipulation de la $\mathrm{PaCO}_{2}$ a été utilisée comme traitement de la PIC dans des cas d'ischémie cérébrale, en pensant que l'hypocapnie pouvait aussi procurer des bénéfices au DSC régional par un volume cérébral inversé. ${ }^{19,20}$ Cependant, une recherche récente suggère que l'hypocapnie n'a pas d'effet favorable sur la distribution du DSC dans le cerveau ischémique, ${ }^{19,20}$ mais, plutôt, peut défavorablement influencer la distribution du débit sanguin. ${ }^{20}$ Lors d'une ischémie cérébrale, on recommande donc de maintenir la $\mathrm{PaCO}_{2}$ à des valeurs normocapniques ou près de ces valeurs.

\section{Optimaliser le contenu du sang en oxygène}

On doit aussi s'assurer d'optimaliser le contenu du sang en oxygène. Ce qui suppose le traitement de l'anémie et l'emploi d'oxygène d'appoint. Chez le patient souffrant d'hypoxie persistante, le monitorage effractif doit être envisagé pour guider la manipulation physiologique.

\section{Expérience clinique portant sur la tension artérielle et des changements de l'hématocrite.}

La littérature fait une large part à l'emploi de la thérapie d'hémodilution, d'hypervolémie et d'hypertension $(\mathrm{HHH})$ pour le traitement de l'ischémie cérébrale. ${ }^{13}$ En théorie, ce traitement améliore la rhéologie sanguine et la livraison d'oxygène au cerveau. Toutefois, l'enthousiasme pour l'emploi énergique de cette technique a été tempéré par la crainte d'effets secondaires cérébraux et systémiques (par ex. l'oedème cérébral, les arythmies cardiaques, l'œdème pulmonaire). ${ }^{11,13}$

À l'opposé, l'hémodilution et l'hypotension induite sont quelquefois utilisées chez des patients sans ischémie cérébrale initiale, pour tenter de réduire la perte sanguine pendant l'intervention chirurgicale 
(par ex. la chirurgie de la colonne). La valeur de cette technique est discutable. On doit noter toutefois que, chez ces patients, la combinaison d'hypotension et d'anémie, intentionnelle ou non, pourrait accroître la possibilité de lésion ischémique au système nerveux central. Le nombre croissant de cas de perte de vision associée à l'hypotension et à l'anémie n'est qu'une des manifestations du problème. ${ }^{21}$

\section{Le controble du glucose sanguin}

Un accroissement de glucose sanguin et de concentration de glucose cérébral au moment d'un accident ischémique cérébral complique l'évolution neurologique post-ischémique. ${ }^{22,23} \mathrm{La}$ raison en est que, pendant les périodes d'hypoxie ou d'anoxie cellulaire, le métabolisme anaérobique du glucose provoque de l'acidose lactique intracellulaire. ${ }^{23}$ Les ions d'hydrogène émanant de ce métablolisme sont directement toxiques pour les neurones et la névroglie; cependant, le lactate ne semble pas toxique. Cette relation entre l'hyperglycémie et la dégradation de l'évolution ischémique a été observée chez les enfants et les adultes. Au contraire, les nouveau-nés ne semblent pas affectés négativement par une hyperglycémie légère.

L'accentuation des lésions neurologiques ischémiques liées au glucose survient dans les deux formes d'ischémie, complète et incomplète..$^{23}$ En outre, l'origine de l'hyperglycémie ne semble pas importante. Plus précisément, l'accentuation de lésion neurologique ischémique liées au glucose a été rapportée avec l'ingestion récente de nourriture, le déséquilibre physiologique, la perfusion de glucose, le diabète sucré et l'usage de corticostréroïdes.22-24

Chez les patients à risque de lésion neurologique ischémique, le traitement comprend le rétablissement de l'équilibre physiologique, le retrait ou l'usage judicieux de liquides contenant du glucose et le traitement de l'hyperglycémie avec l'expansion volumique et l'insuline. L'insuline est bénéfique pour le cerveau en produisant la réduction de la concentration de glucose cérébral et un effet cérébroprotecteur direct indépendant du glucose. ${ }^{23}$

Les concentrations de glucose sanguin doivent être maintenues à l'intérieur des limites de la glycémie normale aussi longtemps que le patient risque de subir une ischémie cérébrale. Si un accident ischémique devait se produire, un accroissement du glucose aussi faible que $40 \mathrm{mg} \cdot \mathrm{dl}^{-1}$ peut aggraver le pronostic. ${ }^{22} \mathrm{En}$ conséquence, aucun patient à risque de subir une ischémie ne devrait présenter des concentrations persistantes de glucose sanguin plus élevées que $\mathbf{2 5 0}$ $\mathrm{mg} \cdot \mathrm{dl}^{-1}{ }^{2,3}$ On doit aussi s'efforcer de ne pas administrer de traitements trop puissants entraînant l'bypogly- cémie, car cela peut provoquer une lésion cérébrale irréversible, peu importe qu'il s'agisse d'un accident ischémique cérébrale ou non. ${ }^{23}$

Pour obtenir d'autres recommandations sur le traitement du glucose sanguin, le clinicien peut consulter l'article récent de Wass et Lanier. ${ }^{23}$

\section{Les stérö̈des}

Les composés stéroïdiens ont été couramment utilisés chez les patients souffrant de troubles neurologiques, $y$ compris les lésions ischémiques cérébrales, en supposant que «les médicamenents ne feront peut-être pas de bien, mais ne feront sûrement pas de mal». Nous savons maintenant que cela est faux. Contrairement à la protection manifestement limitée qu'ils accordent chez les humains souffrant d'une atteinte aiguë de la moelle épinière, ${ }^{25}$ les corticostéroïdes traditionnels peuvent aggraver la lésion cérébrale ischémique. Ce dernier effet est grandement relié aux élévations de glucose sanguin et cérébral induites par les corticostéroïdes. L'hyperglycémie, à elle seule, peut être responsable des effets dommangeables des corticostéroïdes chez les modèles animaux et chez les humains participant à des études sur l'ischémie, et chez l'humain lors d'un essai clinique sur le traumatisme crânien fermé (voir Wass et Lanier $^{23}$ et Wass et coll. ${ }^{24}$ pour consultation). Donc, les corticoïdes traditionnels ne sont pas recommandés pour le traitement de lésions cérébrales ischémiques.

Une recherche récente a tenté de séparer les effets négatifs des corticoïdes liés à l'hyperglycémie de leurs possibles effets bénéfiques antioxydants. Un des résultats de cette recherche est l'introduction de composés aminostéroïdes-21, ou lazaroïdes, dont le tirilazad est le prototype. Ce médicament a annoncé un certain succès pour le traitement de l'ischémie cérébrale chez des modèles animaux, et des résultats préliminaires chez les humains ayant une hémorragie anévrismale sous-arachnoïdienne sont prometteurs. ${ }^{26}$ Mais des résultats ultérieurs décevants retardent actuellement l'utilisation de ce médicament pour l'usage clinique régulier.

\section{Le contrôle de la température}

On reconnait depuis longtemps que d'importantes réductions de température (par ex. jusqu'à $17^{\circ} \mathrm{C}$ ) protègent le cerveau humain. Dans ces conditions, des humains placés sous circulation extracorporelle, peuvent être exposés à des arrêts circulatoires d'une heure sans risque de lésion cérébrale irréversible. ${ }^{6,27}$ Cette technique est quelquefois utilisée pour faciliter la réparation d'anomalies cardiaques ou cérébrovasculaires complexes $^{27}$

Les tentatives de réduction thérapeutique de la température à $<30^{\circ} \mathrm{C}$ en dehors de la circulation 
extracorporelle n'ont présenté que de pauvres résultats. C'est parce que les réductions de température produisent des désordres physiologiques généralisée préjudiciables au patient, peu importe qu'il y ait ischémie cérébrale ou pas. ${ }^{6,27}$

On a longtemps pensé que toute protection cérébrale produite par la médiation de la température était le résultat d'une réduction du taux du métabolisme cérébral. ${ }^{1}$ L'adhésion à cette croyance, combinée à l'expérience susmentionnée d'hypothermie à l'extérieur de la circulation extracorporelle, a peut-être retardé la recherche sur l'effet de faibles réductions de température (c.-à-d. des réductions de température au-dessus de $30^{\circ} \mathrm{C}$ ) sur l'évolution post-ischémique. Nous savons maintenant que ces réductions faibles de température peuvent être très protectrices chez les modèles animaux ${ }^{6,27}$ De plus, une légère hypothermie peut améliorer l'évolution quand elle est amorcée soit avant ou légèrement après l'accident ischémique. ${ }^{27}$

Depuis 1987, de nombreuses études avec des modèles animaux ont démontré de manière cohérente que les réductions de température de $6{ }^{\circ} \mathrm{C}$ protègent le cerveau de lésions ischémiques. ${ }^{6,27} \mathrm{Au}$ contraire, les augmentations de température nuisent à l'évolution. ${ }^{28,29}$ Ces résultats négatifs ne sont pas dus à des changements de vitesse métabolique, comme on a pu le constater dans les études sur le métabolisme du phosphate de haute énergie et sur l'accumulation de lactate. ${ }^{6,27}$ On croit plutôt que l'altération des résultats est causée par une variété de facteurs : a) des changements de l'homéostase ionique (comprenant les flux de calcium et de potassium), b) la stabilité membranaire accrue (comprenant la barrière hémato-encéphalique), c) l'altération de la fonction enzymatique, d) des altérations de la libération ou de la captation des neurotransmetteurs et e) des changements dans la production ou l'élimination de radicaux libres. .,27 $^{6}$

Le changement de température minimal pouvant affecter l'évolution a été caractérisé dans les études de Warner et coll..$^{30}$ et Wass et coll. ${ }^{28}$ Dans la première, les changements de température de $1,2^{\circ} \mathrm{C}$ sont mis en corrélation avec des changements trois fois plus importants de l'étendue de l'infarctus chez un modèle d'ischémie focale chez le rat. Dans la dernière, les changements de température de $1^{\circ} \mathrm{C}$ seulement ont été suffisants pour modifier l'évolution chez un modèle canin d'ischémie complète.

Malheureusement, aucune études ne peut confirmer que l'hypothermie provoquée peut protéger le cerveau humain de lésions ischémiques (bien qu'il y ait une tendance évidente à l'utiliser pour protéger ceux qui souffrent de traumatisme crânien fermé). ${ }^{27,31}$ En attendant de nouvelles recherches, on doit veiller à ce que la réduction de température soit utilisée avec précaution chez l'humain, puisque la réduction excessive (jusqu'à $<35^{\circ} \mathrm{C}$ ) peut augmenter la possibilité d'effets secondaires généralisés. . $^{6,27,32}$

Comme on l'a déja dit, ${ }^{29}$ la fièvre peut compliquer l'évolution à la suite d'une ischémie cérébrale. Albrecht et coll. ont rapporté que les patients hospitalisés à risque de subir des lésions ischémiques cérébrales ont une forte incidence de fièvre $(70 \%$ après une hémorragie sous-arachnoïdienne et $83 \%$ après la réanimation pour arrêt cardiaque) et que les épisodes fébriles demeurent largement non traités. ${ }^{29}$ En se basant sur les données d'études faites en laboratoire, on pouvait s'attendre qu'un traitement plus proactif de la fièvre contribue à l'amélioration de la récupération neurologique post-ischémique.

\section{Utilisation des anesthésiques}

Les anesthésiques peuvent être bénéfiques pour le patient présentant une lésion cérébrale aiguë, et selon une variété de mécanismes, y compris le contrôle des convulsions et de la PIC. On a aussi prêté beaucoup d'attention à l'emploi des anesthésiques comme protecteurs cérébraux directs. C'est l'objet d'une revue récente par Polis and Lanier. ${ }^{33}$

\section{Les barbituriques}

La preuve la plus probante d'un rôle protecteur a été démontré avec les barbituriques. ${ }^{33}$ Ces médicaments, non efficaces pour le traitement de l'ischémie cérébrale associée à l'arrêt cardiaque, ${ }^{34}$ sont utiles pour le traitement de l'ischémie cérébrale focale. ${ }^{33}$

Chez les modèles animaux d'ischémie cérébrale focale, les barbituriques réduisent spécifiquement la taille de l'infarctus. ${ }^{33}$ De plus, Neussmeir et coll. rapportent que l'administration de thiopental a réduit l'incidence de complications neurologiques et psychiatriques postopératoires chez les opérés cardiaques. ${ }^{35}$ C'est le seul exemple humain de protection cérébrale reliée à un anesthésique qu'on ait identifié lors d'une étude prospective randomisée.

La protection cérébrale par les barbituriques a été longtemps attribuée à leur capacité de réduire le taux du métabolisme cérébral et de redistribuer le DSC. ${ }^{33}$ Cette théorie dicte l'emploi de doses importantes de barbituriques pour obtenir une protection cérébrale maximale. Cependant, cette pratique, tout comme la théorie de la protection; ont été récemment mises en question par Warner et coll..$^{36}$ Cette étude a démontré que la protection cérébrale par le pentobarbital n'était pas en corrélation avec la dose de médicament ou avec l'étendue de la dépression métabolique, dans un modèle d'ischémie cérébrale focale chez le rat. 


\section{D'autres aneshtésiques dépresseurs métaboliques}

Bien qu'une variété d'anesthésiques dépresseurs métaboliques aient été évalués pour leurs propriétés cérébroprotectrices, aucun ne se compare aux barbituriques quant à la protection cérébrale qu'ils assurent. Comme l'ont montré, entre autres, Polis et Lanier ${ }^{33}$, la proportion des études qui ont illustré une protection cérébrale s'établit comme suit : barbituriques, 17 sur 19 études; isoflurane, 4 sur 8 ; étomidate, 0 sur 2 et propofol, 1 sur 3 . Fait à noter, l'étomidate $\mathrm{a}$, en fait, aggravé l'évolution selon les deux études citées. Dans cette collection d'études, tous les exemples positifs de protection cérébrale par des non barbituriques se sont produits avec le même modèle (occlusion unilatérale de la carotide plus hypotension provoquée). ${ }^{33}$ Cependant, dans ce modèle, la protection cérébrale ne peut être mise en corrélation avec les changements du taux métabolique, mais plutôt avec les changements de métabolisme adrénergique.

On n'a pas réussi à prouver qu'il y a une meilleure protection cérébrale avec l'usage des non barbituriques chez les humains. ${ }^{33}$ Bien que Michenfelder et coll. aient rapporté que l'isoflurane diminue le «DSC critique» et l'incidence d'ischémie cérébrale pendant l'endartériectomie carotidienne, il n'y a pas d'effet sur les complications à long terme. ${ }^{2}$ Lozada et coll. ont peut-être mieux expliqué la raison de ce phénomème. ${ }^{37}$ En procédant à un examen rétrospectif de la population de patients étudiée par Michenfelder et coll. ${ }^{2}$, ils ont déterminé que $79 \%$ des déficits neurologiques étaient le résultat d'accidents ischémiques postopératoires et, de ce fait, ne devraient pas avoir subi l'influence du choix des anesthésiques peropératoires.

\section{L'usage de médicaments cérébroprótecteurs spéci- fiques à des récepteurs}

\section{Bloqueurs calciques}

L'utilisation chez les humains d'une variété de bloqueurs calciques a été approuvée, mais les indications pour la protection cérébrale humaine est presque exclusivement reliée à l'emploi de la nimodipine dans le traitement du vasospasme cérébral. ${ }^{38} \mathrm{Chez}$ les patients qui ont un vasospasme après une hémorragie sousarachnö̈dienne, la nimodipine améliore l'évolution; toutefois, ce pourrait être le résultat de facteurs autres que des changements de DSC. Plus précisément, disons que la nimodipine pourrait être directement cérébroprotectrice. ${ }^{38}$

Grâce à cette expérience favorable, la nimodipine est couramment utilisée pour la prophylaxie et le traitement du vasospasme dans les cas de rupture d'un anévrisme. ${ }^{26,38}$

\section{Les antagonistes des acides aminés excitateurs}

Il y a un grand nombre de preuves expérimentales chez les modèles animaux que la libération d'acides aminés excitateurs (AAE; ex. : glutamate et aspartate) pendant l'ischémie peut moduler l'évolution postischémique. ${ }^{7,33}$ En outre, les AAE-bloquants peuvent améliorer l'évolution de ces animaux. Toutefois, les AAE-bloquants n'ont pas été acceptés comme traitement de l'ischémie cérébrale chez l'humain, surtout à cause de leurs effets secondaires. Cette famille de médicaments, qui inclue la phencyclidine ("poudre d'ange") et la kétamine, tend à causer des problèmes psychologiques, incluant les hallucinations, et peut abaisser le seuil des crises convulsives. ${ }^{33}$

\section{Sommaire}

Malgré que les recherches récentes centrées sur la protection cérébrales aient eu pour but de développer des médicaments spécifiques à des récepteurs, cet effort n'a actuellement rapporté que peu d'amélioration de l'évolution des patients. Jusqu'à ce que des progrès pharmacologiques permettent cette amélioration, le clinicien et ses patients seront bien servis par l'usage de techniques plus traditionnelles de prévention et de traitement des accidents ischémiques cérébraux. Cette démarche implique des interventions pour a) identifier les patients qui subissent ou qui sont à risque de subir une ischémie cérébrale, et b) changer la physiologie systémique dans une tentative de réduire la durée et la sévérité de tout accident ischémique. La thérapie initiale doit comprendre des interventions pour améliorer la perfusion cérébrale et la capacité de transport de l'oxygène sanguin. Une fois que cela est accompli, des mesures doivent être prises pour contrôler les concentrations de glucose sanguin et traiter la fièvre. Chez des opérés par ailleurs stables, des réductions légères de température peuvent être aussi bénéfiques, pourvu que les réductions de température n'introduisent pas de problèmes physiologiques systémiques et que le patient soit réchauffé avant le réveil, à la suite de l'anesthésie générale. Le choix de l'anesthétique général peut avoir son importance dans le contrôle de la pression intracrânienne et des crises convulsives; cependant, si une protection cérébrale directe est désirée, l'anesthésique de choix serait un barbiturique. Finalement, chez le patient à risque de vasospasme cérébral, le traitement à la nimodipine devrait être envisagé. Mises en commun, ces interventions devraient accroître les chances du patient pour une récupération neurologique optimale après l'ischémie.

\section{Références}

(Voir page R50) 